長鎖ゲルベアルコールより合成した新しい

カチオン界面活性剂の水への溶解挙動とへ

アコンディショナーへの応用

矢作和行 星野值子広田一

\title{
Solution Behavior of New Cationic Surfactants Synthesized by Using Long-chain Guerbet Al- cohols in Water and Their Application to Hair Conditioners
}

\author{
Kazuyuki Yahagi, Naoko Hoshino, and Hajime Hirota
}

\begin{abstract}
The solution behavior of new cationic surfactants, quaternary ammonium salts synthesized by using long-chain Guerbet alcohols, in water was investigtigated by a polarizing microscopic technique, differential scanning calorimetry, and electric conductivity measurements. These surfactants show the gel-liquid crystalline phase transition to be lower than $0^{\circ} \mathrm{C}$ and form lamellar liquid crystal even in cold water and at low concentrations of surfactants. The sorption of cationic surfactants from aqueous solutions onto hair was determined as a function of temperature. The effect of adsorbed cationic surfactants on the critical surface tension and kinetic frictional coefficients of hair surface have been investigated. These surface characteristics of hair treated with quaternary ammonium compounds derived from Guerbet alcohol found to be dramatically improved and this results can be explained by high ability of sorption onto hair. Hair rinses and conditioners having excellent ease of combing or brushing for wet and dry hair can be formulated by the application of those cationic surfactants.
\end{abstract}

\section{1. 緒 言}

カチオン活性剤は, 毛髮飞柔軟性, 平滑性, 带電防止 性を付与することを目的として，へアリンスやへアコン ディショナーに使用されている。種々のタイプのカチオ ン活性剂が知られているが，炭素数が16から 22 の間の直 鎖状モノまたはジ長鎖アルキル基を有する第 4 級アンモ ニウム塩が，毛髪化粧品に乹いて最も広く使用されてい る11。ヘアリンスやュンディショナーの性能は，カチオ ン活性剂が毛髮に吸着し2)，水ですすいだ後でも毛髮上 飞残存 $\left.{ }^{31}, 4\right)$ するために発現する。直鎖状のカチオン活性 剤は, アルキル鎖長の長い子のほど柔軟性, 平滑性の効

花王秼東京第 1 研究所: $\mathbf{T} 131$ 東京都墨田区文花 2 $1-3$

Tokyo Research Laboratories, Kao Corporation: 2-1-3 Bunka, Sumida-ku, Tokyo 131, Japan
果が高いことが報告されているが5゙,6)，その理由につい ては不明な点が多い。

一般に，直鎖了ルキル基を有する界面活性剂は，アル キル鎖長が長くなるにつれてゲル一液晶転移温度または

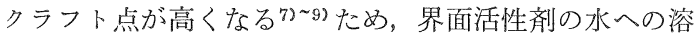
解性は低くなる。従って, 通常の使用条件では, これら の界面活性剤はゲル相 (水和固体) として水に分散して いるため, 本来の性能を十分に発揮していないものと考 兄られる。カチオン活性剂の溶存状態と毛髪への吸着挙 動は，それらが毛髮の表面物性を変劣る剤であるといら 実用上の観点から特に興味深い。しかも, 美容上, 毛髮 を機械的なダメージから守るために，毛髪のマネージャ ビリティーや wet 打よび dry 時のくし通り性にすぐれ た毛髮化粧料の開発が望まれている。

本研究では, 炭素数が16から280ゲルベアルコールを 用いて新しいタイプのカチオン活性剂を合成し，そ机ら 
の水への溶解挙動を調べた。また，それらのカチオン活 性剂水溶液で毛髪を処理した場合の毛髪への吸着性, 毛 髪表面特性の変化を, 従来の直鎖タイプのカチオン活性 剂と比較検討した。その結果, 我々は, 長鎖ゲルベアル コールより合成した新しいカチオン活性剂は，低温／低 濃度から液晶を形成し, 毛髮への吸着量が多いことを見 出し、それらをへアリンスやコンディショナーに応用す ることの有意性と重要性を議論する。

\section{2. 実 験}

\section{1 試 料}

新しいカチオン活性剤は，次のようにして合成した。

$$
\underset{\mathrm{R}}{\mathrm{RCH}_{2} \mathrm{CH}_{2} \mathrm{CHCH}_{2} \mathrm{OH}} \underset{\mathrm{Cu} / \mathrm{Ni} \text { Cat. }}{\stackrel{\left(\mathrm{CH}_{3}\right)_{2} \mathrm{NH}}{\longrightarrow}}
$$<smiles>[R]CCC([R])CN(C)C(=O)N(C)C(C)=O</smiles><smiles>[R]CCC([R])C[N+](C)(C)C</smiles>

すなわち，それぞれ相当する長鎖ゲルベアルコールと ジメチルアミンを, 触媒存在下で $\mathrm{H}_{2}$ ガスを流しながら 反応させ第 3 級アミンを合成した。得られた第 3 級アミ ンは減圧蒸留により精製した後, 水一イソプロパノール 混合溶媒中で炭酸ナトリウム存在下，メチルクロライド と反応させ，目的の第 4 級アンモニウム塩を得た。反応
生成物は，アセトンより再結晶を行い精製した。長鎖ゲ

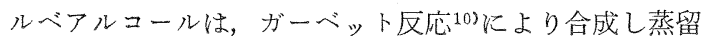
により精製して用いた。ジステアリルジメチルアンモニ ウムクロライドは Sherex Chemical Company, Inc., ベヘニルトリメチルアンモニウムクロライドは Hoechst $\mathrm{AG}$ より，ステアリルトリメチルアンモニウムクロライ ドは東京化成 Ltd.より購入したものを，アセトンより 再結晶を行い精製した。セチルアルコールとプロピレン グリコールは東京化成 Ltd. の試薬グレードを用いた。

Table-1に用いたカチオン活性剤の略号を示した。

\section{2 会合体形成濃度の測定}

カチオン活性剂水溶液の単分散飽和濃度 (臨界ミセル 濃度, CMC) は, 水不溶性の色素, Yellow OB, の可溶 化から求めた ${ }^{11)}$ 。活性剂水溶液之少量の固体 Yellow $\mathrm{OB}$ を含む密封されたテストチューブを， $30^{\circ} \mathrm{C} て ゙ 48$ 時間振 とうした。Yellow OB の可溶化量は， $447 \mathrm{~nm}$ での吸光 度測定により決定した。CMC は, 活性剂濃度の増加に ともなら可溶化量のいちじるしい変化から求めることが 出来る。

\section{3 相転移温度および電気伝導度の測定}

活性剤サンプルのクラフト点またはゲル一液晶転移温 度 $(\mathrm{Tc})$ は, 示差走査熱量測定から求めた。示差走査熱 量測定 (DSC) は，セイコー電子工業侏製，Type SSC580 DSC-10 装置で行なった。サンプル溶液（～60 $\mu \mathrm{l} ）$ を銀製のセルに密封し, $1.0^{\circ} \mathrm{C} / \mathrm{min}$ の割合で加熱した。 電気伝導度は, 東亜電波社製 Model CM-6A 型 Conductivity Meter を用いて, $0.5^{\circ} \mathrm{C} / \mathrm{min}$ の割合で昇温し ながら測定した。サンプル濃度は，2.0wt\%で行なった。

Table-1 Cationic Surfactants Used in This Work and Their Abbreviations

\begin{tabular}{llc}
\hline \multicolumn{1}{c}{ Surfactant name } & Molecular structure & AbbrevIatIon \\
\hline $\begin{array}{l}\text { 2-hexyldecyltrimethylammonium } \\
\text { chloride }\end{array}$ & $\mathrm{C}_{8} \mathrm{H}_{17} \mathrm{CHCH}_{2} \mathrm{~N}\left(\mathrm{CH}_{3}\right)_{3} \mathrm{Cl}$ & $\mathrm{g}-\mathrm{C} 16 \mathrm{TAC}$ \\
$\begin{array}{l}\text { 2-octyldodecyltrimethylammonium } \\
\text { chloride }\end{array}$ & $\mathrm{C}_{6} \mathrm{H}_{13}$ & $\mathrm{~g}-\mathrm{C} 20 \mathrm{TAC}$ \\
$\begin{array}{l}\text { 2-decyltetradecyltrimethylammonium } \\
\text { chloride }\end{array}$ & $\mathrm{C}_{12} \mathrm{H}_{25} \mathrm{CHCHCH}_{2} \mathrm{~N}\left(\mathrm{CH}_{3}\right)_{3} \mathrm{Cl}\left(\mathrm{CH}_{3}\right)_{3} \mathrm{Cl}$ & $\mathrm{g}-\mathrm{C} 24 \mathrm{TAC}$ \\
$\begin{array}{l}\text { 2-dodecylhexadecytrimethylammonium } \\
\text { chloride }\end{array}$ & $\mathrm{C}_{14} \mathrm{H}_{29} \mathrm{CHCH}_{21} \mathrm{~N}(\mathrm{CH})_{3} \mathrm{Cl}$ & $\mathrm{g}-\mathrm{C} 28 \mathrm{TAC}$ \\
stearyltrimethylammonium chloride & $\mathrm{C}_{12} \mathrm{H}_{25}$ & $\mathrm{n}-\mathrm{C} 18 \mathrm{TAC}$ \\
behenyltrimethylammonium chloride & $\left.n-\mathrm{C}_{18} \mathrm{H}_{37} \mathrm{~N}_{(\mathrm{CH}} \mathrm{CH}_{3}\right)_{3} \mathrm{Cl}$ & $\mathrm{n}-\mathrm{C} 22 \mathrm{TAC}$ \\
distearyldimethylammonium chloride & $n-\mathrm{C}_{22} \mathrm{H}_{45} \mathrm{~N}\left(\mathrm{CH}_{3}\right)_{3} \mathrm{Cl}$ & 2n-C18DAC \\
\hline
\end{tabular}




\section{4 相図の作成}

所定の組成のアンプルを作成し，恒温槽中で観察し た。高濃度の組成のものは一度高温飞して混合してから 観察した。液晶は, 偏光板を用いて検出し, 場合により ホットステージ付きの偏光顕微鏡で観察した。

\section{5 毛髮への吸着量測定}

毛髮は, 日本人女性の健常毛 (非化学処理毛) をシャ ンプーで洗浄し，十分流水ですすいだ後，エタノールで 24時間抽出し，イオン交換水で十分洗ってから風乾し た。これを長さ約 $10 \mathrm{~cm}$, 重さ $0.50 \mathrm{~g}$ の毛束にして用い た。カチオン活性剤の吸着処理は，0.50g の毛髪をイオ ン交換水中に浸せきし，水で膨潤させた後，余分な水を ふきとり恒温槽中の所定温度のカチオン活性剂 $2.0 \mathrm{wt} \%$ 溶液 $20 \mathrm{~g}$ 中に 10 分間浸せきする。浸せき後，余分な溶液 をふきとり同温度のイオン交換水 $300 \mathrm{~m} 1$ 中ではげしく振 とうさせながら 5 秒間すすぎ処理を行なった。このすす ぎ処理を, 3 回くり返し行なった後, 十分風乾した。毛 髪に吸着したカチオン活性剤は，クロロホルム $20 \mathrm{ml}$ を 溶媒として 5 分間超音波処理を行い抽出した。抽出液を, 新しいクロロホルムに拉きかえて抽出操作を合計 3 回行 なった。エバポレーターで $60 \mathrm{ml}$ の抽出液からクロロホ ルムを除去した後，1ないし $2 \mathrm{ml}$ のクロロホルムを加 えてカチオン活性剂を溶解した。カチオン活性剤の量 は, Orange II との反応により定量した ${ }^{12), 13) 。 ~}$

\section{6 毛髪の臨界表面張力}

それぞれの毛髪サンプルの臨界表面張力 $\left(\gamma_{\mathrm{e}}\right)$ は, Wetting force 測定 ${ }^{14)}$ により求めた。平均直径約 $60 \mu \mathrm{m}$ の毛髮を約 1500 本束放, 長さ $3 \mathrm{~cm}$, 直径 $4 \mathrm{~mm}$ の上を しっかり固定した毛束を作成し測定に用いた。浸せさ液 は, 水一プタノール混合溶液を用い, 混合比を変えて浸 せき液の表面張力 $\left(\gamma_{\mathrm{L}}\right)$ をコントロールした。但し，毛 束間に浸透した液体の荷重と, 毛束の浮力の補正を行な った。前進接触角 $\left(\theta_{\mathrm{a}}\right)$ の cosine と, 後退接触角 $\left(\theta_{\mathrm{r}}\right)$ の cosine の差, $\left(\cos \theta_{\mathrm{r}}-\cos \theta_{\mathrm{a}}\right)$, を $1 / \sqrt{\gamma_{\mathrm{L}}}$ 飞対し てプロット ${ }^{15)} し,\left(\cos \theta_{\mathrm{r}}-\cos \theta_{\mathrm{a}}\right)$ がゼロになる点から と学計算した。

\section{7 動摩摖係数測定}

毛髮の動摩擦係数は, 日本レオロジー機器䄳製 NRFII 型摩擦係数計を用いて測定した ${ }^{16)}$ 。ナイロン製のプー リーにかけた一本の毛髪の両端に，0.465 g の重りをか けて,プーリーを5 rpmで回転させて測定を行なった。 各試験液について, 毛髮 10 本以上測定し平均値を求めた。

\section{8 ブロープロセスにおけるブラッシングカの測定} 日本人女性の健常毛 $20 \mathrm{~g}$ (長さ約 $28 \mathrm{~cm}$ ) を束衩, シ
ヤンプーで洗浄した後, モデルコンデ イショナー $2.0 \mathrm{~g}$ を塗布した。流水で30秒間すすいだ後，タオルドライを 行なった。ブラシ付きのドライヤーを用いて，ブローし ながらブラッシングを行ない，毛束にかかる力，ブラッ シング力, を測定した ${ }^{17), 18)}$ 。ブラッシングは, 毎分30ス トロークで行ない, タオルドライからドライまでを6 分 間で行なった。

$$
\begin{array}{cc}
\text { モデルコンディショナーの組成を以下に示す。 } \\
\text { カチオン活性剤 } & 2.0 \mathrm{wt} \% \\
\text { セチルアルコール } & 3.0 \mathrm{wt} \% \\
\text { プロピレングリコール } & 2.0 \mathrm{wt} \% \\
\text { イオン交換水 } & 93.0 \mathrm{wt} \%
\end{array}
$$

$70^{\circ} \mathrm{C}$ 飞加熱した水に, 同温度に加熱したカチオン活性 凰，七チルアルコールおよびプロピレングリコールの混 合溶液を攪找しながら徐々に加えた。攪拌しながら室温 まで冷却して，モデルコンディショナーを調製した。

\section{3. 給果と考察}

\section{1 カチオン活性剤の水への溶解挙動}

Fig.-1 に長鎖ゲルベアルコール誘䆃 4 級塩の会合体 形成濃度 $(\mathrm{CMC})$ と, 長鎖アルキル基の炭素数の関係を プロットした。直鎖モノアルキルまたはジアルキル4 級

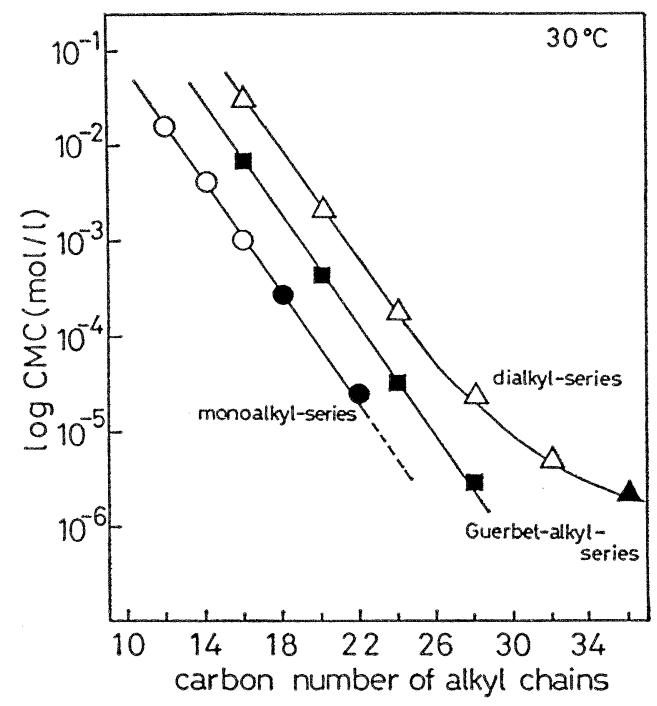

Fig. -1 The relationship between the saturation concentration (CMC) and hydrocarbon chain length of surfactants at $30^{\circ} \mathrm{C}$. The data was obtained from the solubilization $(\bullet, \mathbf{\Lambda}, \mathbf{\square})$ and reference 19 $(O, \triangle)$. 
アンモニウム塩のデータ19)も同時に示した。一般に，イ オン性界面活性剤のアルキル鎖長と, CMCのロガリズ ムの間には，次の関係式が知られている7。

$$
\log \mathrm{CMC}=\mathrm{A}-\mathrm{BN}
$$

ここで，Nはアルキル基の炭素数（ジアルキル型の場

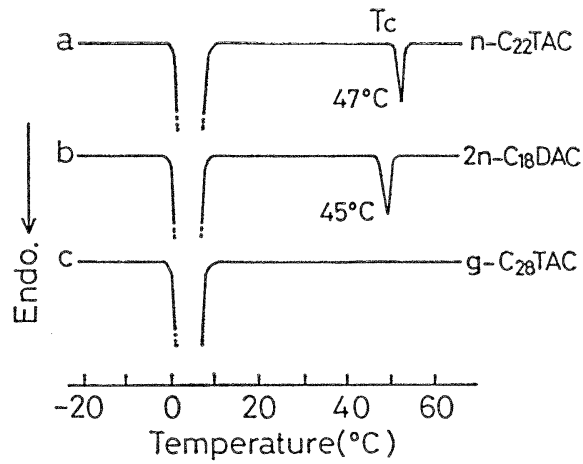

Fig. -2 Typical DSC curves of cationic surfactwater system. The sample of the 2.0 wt $\%$ surfactant solution $(\sim 60 \mu 1)$ was sealed in a silver cell and heated at the rate of $1.0^{\circ} \mathrm{C} / \mathrm{min}$. The endthermal peaks around $0^{\circ} \mathrm{C}$ correspond to the melting of ice.

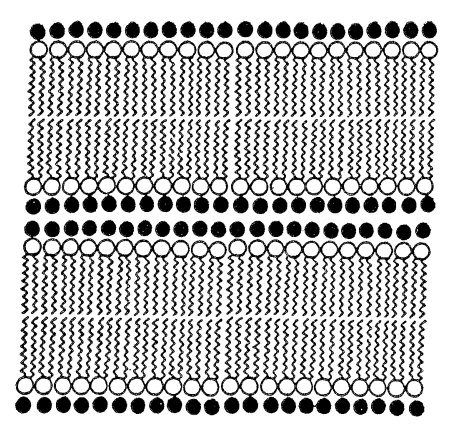

- counterion

(1) hydrated solid(gel) phase
合は 2 本の和)， A， B は活性剂によって決まる定数を示 す。

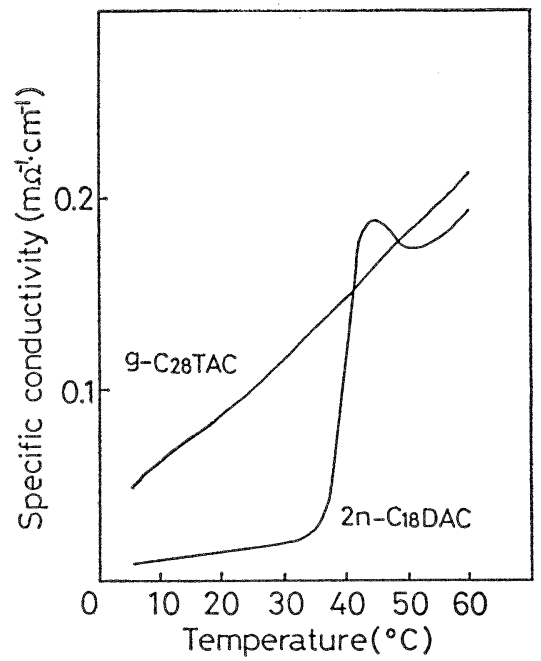

Fig. -3 Changes in the specific conductivity of cationic surfactant aqueous solution with temperature. The concentration of sample solutions was kept constant at $2.0 \mathrm{wt} \%$.

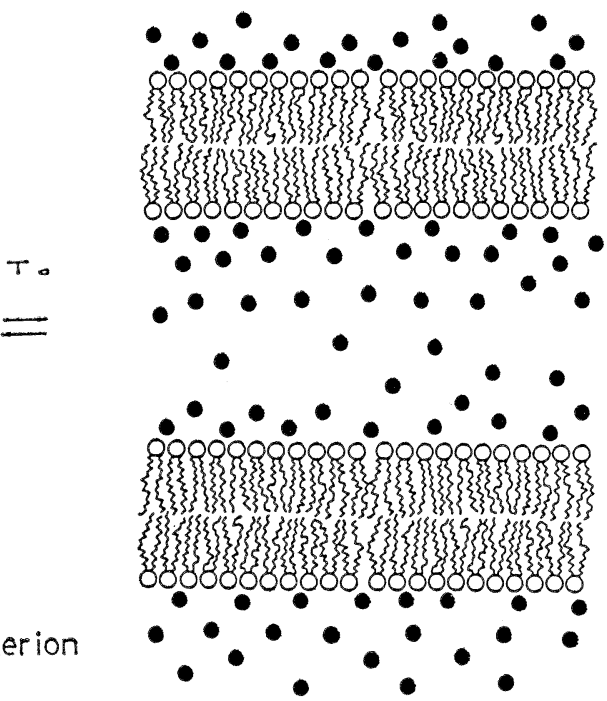

(II) liquid crystalline phase

Fig. -4 Schemetic models of dialkyldimethylammonium chloride in water for the hydrated solid (gel) phase ( I ) and liquid crystalline phase (II). The open circles represent the polar head groups, the closed circles the counterions, and the wiggly lines the long alkyl chains. 
長鎖ダルベアルコールより合成した新しいカチオン界面活性剤の水への溶解挙動とへアコンディショナーへの応用

(1)式に従って，界面活性剂の CMC はアルキル鎖長が 増すにつれていちぢるしく減少している。Fig.-1に抌い てモノアルキル型，ジアルキル型，ゲルベアルキル型 は，それぞれ互いに平行な直線上にあり，アルキル基の 構造による影響は，同族列に関する定数と考えられるA 項に現れている。

ゲルベアルキル型は，その分子構造に叔いてモノアル キル型とジアルキル型の中間的形状をしていることか ら， CMC のアルキル鎖長依存性に和いて，両者の中間 的挙動を示しているものと考えられる。

Fig. - 2 に代表的な試料の DSC カーブを示した。直鎖 状のカチオン活性剤の場合, $-20^{\circ} \mathrm{C}$ から昇温していく と, $0^{\circ} \mathrm{C}$ で氷の融解による吸熱ピークが現れ， $0^{\circ} \mathrm{C}$ 以上 でアルキル鎖の融解に基づく吸熱ピークが観察され, こ れがゲル一液晶 (ミセル溶液) 転移， $\mathrm{T}_{\mathrm{e}}$ に相当する。一 方，ゲルベアルキル型の場合は， $-20^{\circ} \mathrm{C}$ から $90^{\circ} \mathrm{C}$ の 温度範囲では承の融解による吸熱ピーク以外は観測され ない。

Fig.-3 に電気伝導度の温度変化を示した。g-C 28 TAC の系は, 温度の上昇にともなって電気伝導度は単調に増 加している。 $2_{\mathrm{n}}-\mathrm{C}_{18} \mathrm{DAC}$ の系は, $\mathrm{T}_{\mathrm{c}}$ 付近で伝導度の急 激な増加が見られる。この結果から， $\mathrm{T}_{\mathrm{c}}$ を境にアルキル 基の融解と同時に親水基の融解が起こっているものと考 えられる(Fig. -4$) 。$

$2 \mathrm{n}-\mathrm{C}_{18} \mathrm{DAC}$ 一水, $\mathrm{g}-\mathrm{C}_{28} \mathrm{TAC}$ 一水系の相図をとれぞれ Fig.-5, Fig.-6 に示した。 $2 \mathrm{n}_{\mathrm{n}}-\mathrm{C}_{18} \mathrm{DAC}$ の系では, $\mathrm{T}_{\mathrm{e}}$ が 室温より高くなっているが， $\mathrm{g}-\mathrm{C}_{28} \mathrm{TAC} の$ 系では，広い

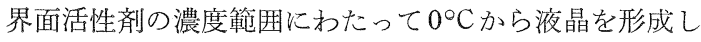
ていることがわかる。Table-II に各種カチオン活性剤 水溶液の溶解挙動をぬとめた。アルキル基の炭素数が多 いカチオン活性剤に打いては，非常に低濃度で液晶（ゲ ル）相が形成される。一方，アルキル基が直鎖状のカチ オン活性剤は，アルキル基の炭素数が多くなるにつれて $\mathrm{T}_{\mathrm{c}}$ が高くなり，ゲルベアルキル型の場合はいずれる $\mathrm{T}_{\mathrm{c}}$ が $0^{\circ} \mathrm{C}$ 以下である。この $\mathrm{T}_{\mathrm{c}}$ の異常な挙動は, 分岐アル キル基によって活性剤分子の結晶性が低下したためと考 党える。

\section{2 カチオン活性剂の毛鬁への吸着}

カチオン活性剤の毛髪への吸着に和ける温度依存性を Fig.-7 に示した。いずれの活性剤に対しても, 吸着量 は温度とともに増加している。n-C $\mathrm{C}_{22} \mathrm{TAC}$ 执よび $2_{\mathrm{n}}-\mathrm{C}_{18}$ $\mathrm{DAC}$ の系では，系の $\mathrm{T}_{\mathrm{c}}$ を境に吸着量は急激に増加して いる。カチオン活性剤の毛髮への吸着現象は, 主にイオ ン的な相互作用と眯水的な相互作用によると考学られて

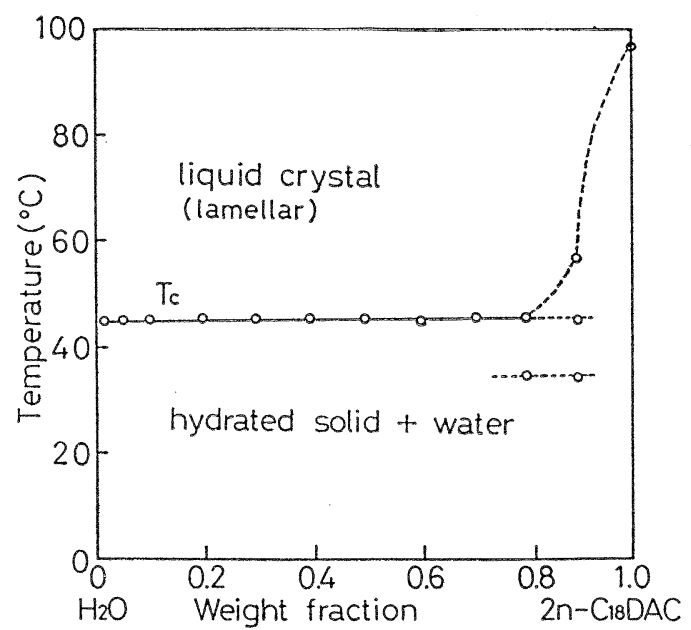

Fig. -5 Phase diagram of the $2 \mathrm{n}-\mathrm{C}_{18} \mathrm{DAC}-$ water system. Tc represents the transition temperature between hydrated solid (gel) and liquid crystalline phases.

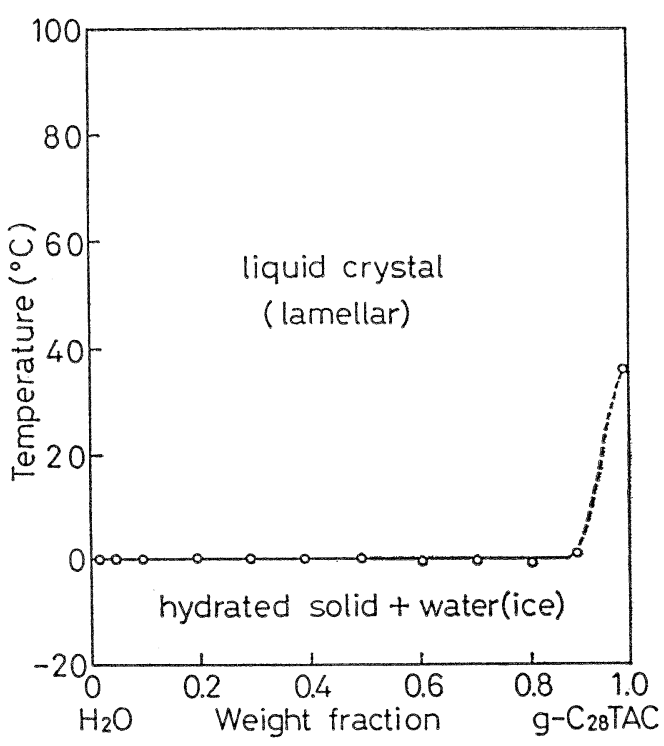

Fig. -6 Phase diagram of $\mathrm{g}-\mathrm{C}_{28}$ TAC-water system.

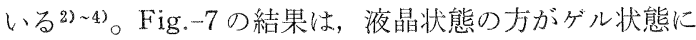
比べて毛髪とのイオン的な相互作用が，カチオン活性剂 の対イオンの解離状態が変化することにより,ょり強く なることを示唆している。一方，温度とともに $\mathrm{g}-\mathrm{C}_{28}$ $\mathrm{TAC}$ の吸着量が増加するのは, 主に毛髮中へのカチオ ン活性剤の浸透によるものと思われる。 
Table-II Solution Behaviors of Various Cationic Surfactants in Water

\begin{tabular}{cccc}
\hline surfactant & $\mathrm{CMC}(\mathrm{mol} / \mathrm{l})$ & $\mathrm{Tc}\left({ }^{\circ} \mathrm{C}\right)$ & appearance of 2.0 wt $\%$ solution at $25^{\circ} \mathrm{C}$ \\
\hline $\mathrm{g}-\mathrm{C}_{16} \mathrm{TAC}$ & $6.3 \times 10^{-3}$ & $<0$ & micellar solution \\
$\mathrm{g}-\mathrm{C}_{20} \mathrm{TAC}$ & $3.5 \times 10^{-4}$ & $<0$ & liquid crystal (lamellar) \\
$\mathrm{g}-\mathrm{C}_{24} \mathrm{TAC}$ & $3.2 \times 10^{-5}$ & $<0$ & liquid crystal (lamellar) \\
$\mathrm{g}-\mathrm{C}_{28} \mathrm{TAC}$ & $3.3 \times 10^{-6}$ & $<0$ & liquid crystal (lamellar) \\
$\mathrm{n}-\mathrm{C}_{18} \mathrm{TAC}$ & $2.4 \times 10^{-4}$ & 18 & micellar solution \\
$\mathrm{n}-\mathrm{C}_{22} \mathrm{TAC}$ & $2.5 \times 10^{-5}$ & 47 & hydrated solid (gel) \\
$2 \mathrm{n}-\mathrm{C}_{18} \mathrm{DAC}$ & $2.5 \times 10^{-6}$ & 45 & hydrated solid (gel) \\
\hline
\end{tabular}

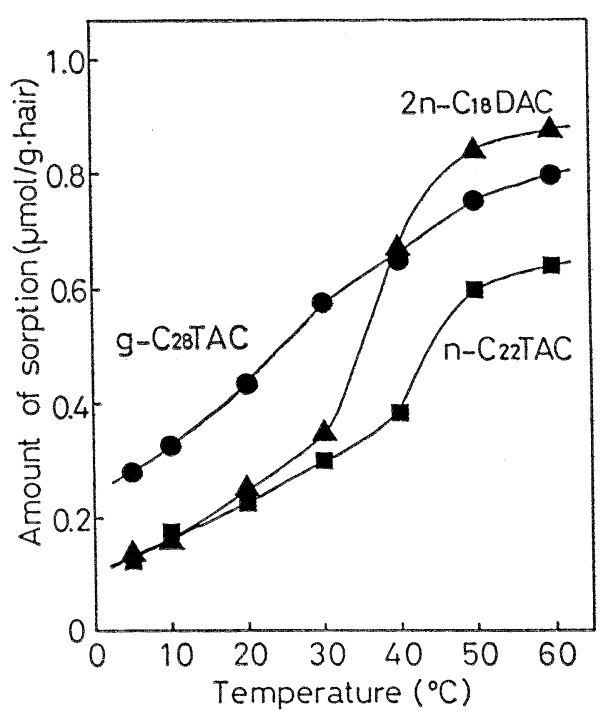

Fig. -7 Effect of temperature on the sorption of cationic surfactants by normal hairs. The Concentration of sample solutions was kept constant at $2.0 \mathrm{wt} \%$ and the immersion time at $10 \mathrm{~min}$.

毛髪にカチオン活性剤を有効に吸着させるためには, T c 以上の温度で処理することが重要である。実際に， $0^{\circ} \mathrm{C}$ から液晶を形成している $\mathrm{g}-\mathrm{C}_{28} \mathrm{TAC}$ 系では, $40^{\circ} \mathrm{C}$ 以下の温度範囲に扣いて他のカチオン活性剤の約 2 倍の 吸着量が得られる。従って，g-C $\mathrm{C}_{28} \mathrm{TAC}$ は, ヘアリンス やコンディショナーの通常の使用温度に扣いて垄髪への 吸着性が高いことから，毛髮表面特性を大きく改善する ことが期待される。

\section{3 カチオン活性剤水溶液で処理した毛髪の表面 物性}

Wetting force 測定より, きれいな健常毛の臨界表面 張力 $\left(\gamma_{\mathrm{c}}\right)$ の值は, 約 $31 \mathrm{dyn} / \mathrm{cm}$ となった。この值は,
損傷のないきれいな羊毛㵶維の值, $30.1 \mathrm{dyn} / \mathrm{cm}^{20)}$, と比 較してほぼ妥当なものと思われる。また，ブリーチ処理 によって化学的にダメージした毛髪の $\gamma_{0}$ の值は, 損傷 のない毛髪の值より高くなることが報告されている211。 実際に，3回ブリーチ処理を行なった毛髪について同様 に測定した結果， $\gamma_{\mathrm{c}}$ の值は約 $34 \mathrm{dyn} / \mathrm{cm}$ が得られ，ブ リーチ処理した毛髪表面は明らかに親水性の方に变化す る。

次に, カチオン活性剤水溶液で処理した毛髪の $\gamma_{\mathrm{e}}$ を 求めた（Fig.-8）。 $\gamma_{0}$ の值は, カチオン活性剤が毛髪上 に吸着することによって低下することがわかる。しか も, カチオン活性剤の種類に大きく依存し, $\mathrm{n}-\mathrm{C}_{18} \mathrm{TAC}$ $<2 \mathrm{n}-\mathrm{C}_{18} \mathrm{DAC}, \mathrm{n}-\mathrm{C}_{22} \mathrm{TAC}<\mathrm{g}-\mathrm{C}_{28} \mathrm{TAC}$ の順で $\gamma_{\mathrm{c}}$ の值 は大きく低下している。この結果から, 毛鬆へのカチオ ン活性剤の吸着量が多い汪ど $\gamma_{0}$ の值は低くなり, 吸着 量がモル数で同程度の場合には，モノアルキルタイプよ

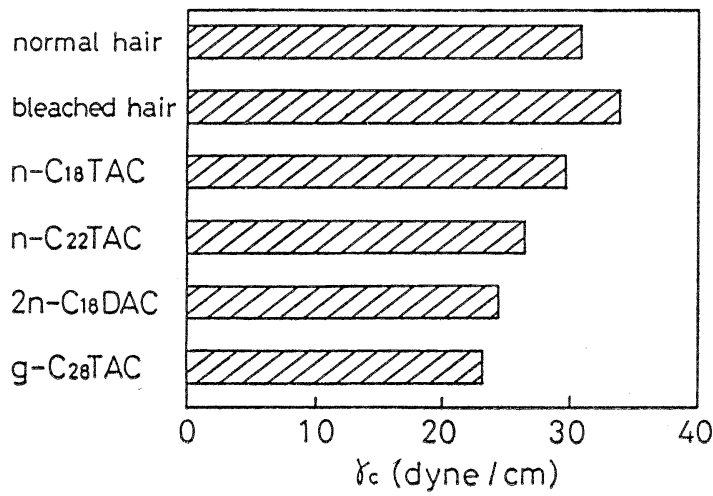

Fig. -8 Effect of sorbed cationic surfactants on the critical surface tension of hair. The values of $\gamma_{c}$ was estimated from the wetting force measurement. The normal and bleached hair were washed out with methanol and dried before measurement. 


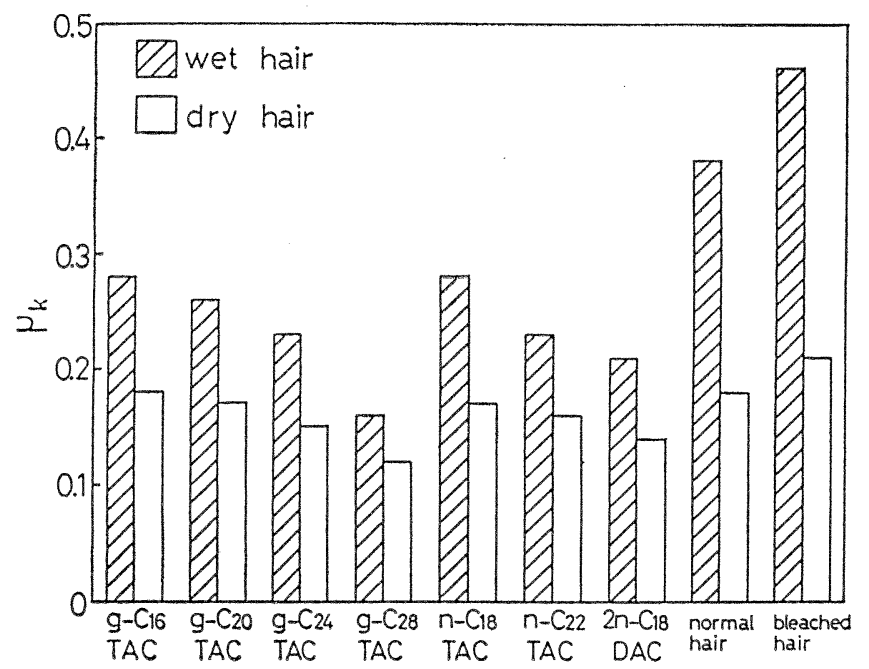

Fig. -9 Effect of sorbed cationic surfactants on the kinetic frictional coefficient of wet and dry hair fibers.

りもジアルキルタイプの方が，毛髪表面をより密にアル

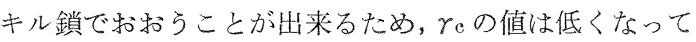
いると考觉られる。

カチオン活性剤で処理した毛髮纎維のWetとDry時 の動摩擦係数, $\mu_{\mathrm{k}}$, を Fig.-9 に示す。ブリーチ妈理毛 は，非常に高い $\mu_{\mathrm{k}}$ の值を示している。カチオン活性剂 で処理した健常毛は、いずれもきれいな健常毛の $\mu_{\mathrm{k}} よ り$ 牛低い值を示す。特た, $\mathrm{g}-\mathrm{C}_{28} \mathrm{TAC}$ は低い $\mu_{\mathrm{k}}$ の值を示 しており，毛髮表面特性を変えるのに有用な活性剤であ る。

Fig. -10に, $\gamma_{\mathrm{c}}$ と $\mu_{\mathrm{k}}$ の関係をプロットした。Wet毛和 よび Dry 毛いずれの場合も $\gamma_{\mathrm{c}}$ が低くなるほど $\mu_{\mathrm{k}}$ が減 少していることがわかる。Vinylidene chloride-acrylonitrile copolymer のらすいフィルム上での, いくつか の脂肪族潤滑剤の挙動と潤滑されたポリマ一表面の性質 について, Owensは研究している22。彼は, 潤滑された ポリマーフィルムの摩擦係数と, そのぬれによる臨界表 面張力の間に相関があることを示した。それによると, ポリマー表面が完全に潤滑剂でお和われる時には，低接 着性で低摩擦係数の低エネルギー表面が形成される。力 チオン活性剤で処理した毛髮表面の場合にも， $\mu_{\mathrm{k}}$ 姿低下 させる効果は，活性剤の毛髮への吸着量によって同様に 説明される。

\section{4 新しいカチオン活性剤のヘアコンディショナー への応用}

Fig.-11 にモデルコンディショナーで処理した後の毛

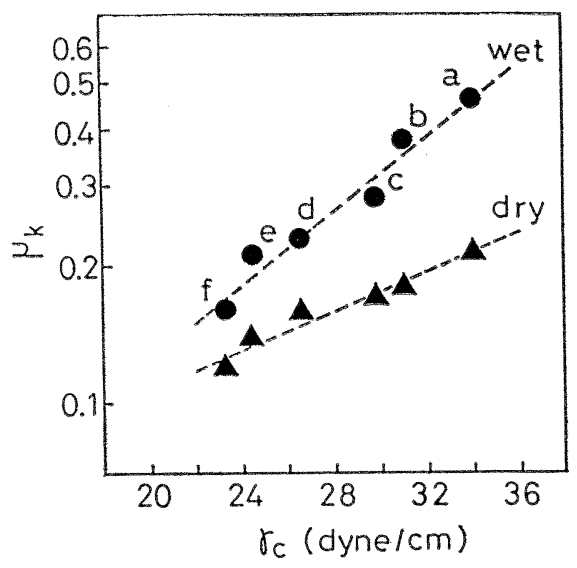

Fig. -10 Plots of kinetic frictional coefficient vs critical surface tension for wet $(\bullet)$ and dry ( hairs: a, clean bleached hair; b, clean normal hair; $c, n-C_{18}$ TAC; d, n-C 22 TAC; e, $2 \mathrm{n}-\mathrm{C}_{18} \mathrm{DAC}$; and $\mathrm{f}, \mathrm{g}-\mathrm{C}_{28} \mathrm{TAC}$.

束のブラシ通り性を示した。罒には，Wet（左側）から Dry（右側）までの乾燥過程（ブロープロ 七大）を連繶 的に示してあり，プロープロセスに特いて，ブラシ通り 力は乾燥直前の時 (毛束の水分量〜 30\%) に最高の值を 記録していることがわかる。クシ・ブラシ通り性は，多 くのへアケア製品の性能を判断する上で, ひとつの重要 なファクターである。しかも，ブラッシングやコーミン 


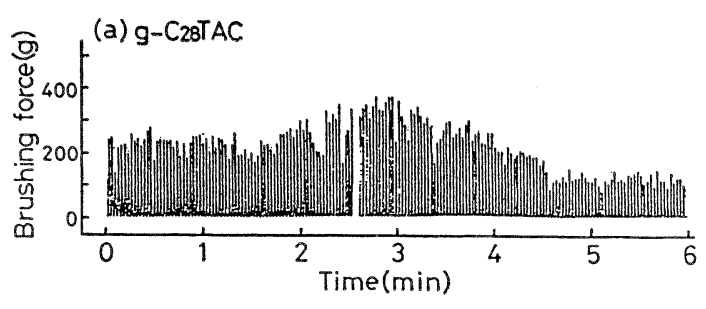

(b) n-Ci8TAC
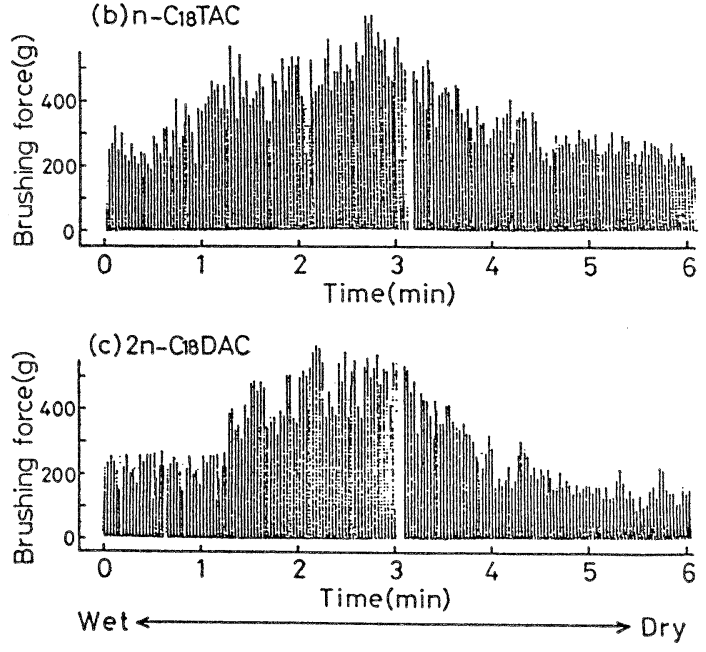

Fig. -11 Changes in brushing force of hair tufts as a function of blowing time with hair drier. The tufts of hair were washed with ordinary shampoo and rinsed with warm water ane then treated with model conditioners formulated with (a)g-C ${ }_{28} \mathrm{TAC}$, (b) n$\mathrm{C}_{18} \mathrm{TAC}$, and (c) $2 \mathrm{n}-\mathrm{C}_{18} \mathrm{DAC}$. The condition of hair tufts gradually changes from wet (the left-hand side of figure) to dry (the right-hand side) with the passage of blowing time.

グからのメカニカルなダメージの程度は，ブラッシング やコーミングを行なっている間に髪にかかる力に直接比 例する。今回新しく開発された長鎖ゲルベアルコール誘 導 4 級塩 ( $\left.\mathrm{g}-\mathrm{C}_{28} \mathrm{TAC}\right)$ を配合したモデルコンディショナ 一は, 従来のカチオン活性剤と大きく異なり, Wetから Dry まで低いブラシ通り力を維持することが可能であ り，その結果，ブラッシングやくし通しによる機械的な ダメージから毛髪を等る効果が非常に高いことを示唆し ている。

\section{4. 総 括}

我々は，幸運にも長鎖ゲルベアルコールから新しいタ
イプのカチオン活性剤を開発し，これらのカチオン活性 剤は，非常に優れた性能を有するへアリンスやュンディ ショナーに応用が可能であることを見出した。

\section{文 献}

1) Quack, J.M., Quaternary ammonium compounds in cosmetics, Cosmetics \& Toiletries, 91(2), 35-52 (1976). Gerstein, T., An introduction to quaternary ammonium compounds, Cosmetics \& Toiletries, 94(11), 32-41 (1979).

2) Scott, G.V., Robbins, C.R., and Barnhurst, J.D., Sorption of quaternary ammonium surfactants by human hair, J. Soc. Cosmetic Chemists, 20, 135-152 (1969).

3) Tokiwa, F., Hayashi, S., and Okumura, T., Hair and surfactants, in "Biology and disease of the hair", pp 631-640, 1976, University of Tokyo Press, Tokyo.

4) Finkelstein, P. and Laden, K., The mechanism of Conditioning of hair with alkyl quaternary ammonium compounds, Applied Polymer Symposium, 18, 673-680 (1971).

5) Evans, W.P., Cationic fabric softeners, Chemistry and Industry, 5(7), 893-903 (1969).

6) Harusawa, F., Kato, T., and Tanaka, M., The sorption of surfactants by human hair and textile fibers and kinetic frictional coefficient of human hair, J. Soc. Cosmet. Chem. Japan, 15(3), 225-232 (1981).

7) Shinoda, K., Nakagawa, T., Tamamushi, B., and Isemura, T., "Colloidal Surfactants", pp 7-9, 1963, Academic Press, New York.

8) Kunieda, H., and Shinoda, K., Krafft points, critical micelle concentration, surface tension, and solubilizing power of aqueous solutions of fluorinated surfactants, J. Phys. Chem., 80(22), 2468-2470 (1976).

9) Suzuki, T. and Takei, H., Solution behavior and association structures of long-chain monoalkyl phosphates, J. Chemical Society of Japan, No.5, 633-640 (1986).

10) Buehler, C.A. and Pearson, D.E., "Survey of Organic Syntheses”, vol. 1, pp 240, 1970, John Wiley \& Sons, Inc., New York. 
11) Tsujii, K., Saito, N., and Takeuchi, T., Viscoelastic and some colloid chemical properties of partially neutralized alkenylsuccinates in dilute aqueous solutions, J. Colloid Interface Sci., 99, 553-560 (1984).

12) Few, A.V. and Ottewill, R.H., A spectrophotometric method for the determination of cationic detergents, J. Colloid Sci., 11, 3438 (1956).

13) Kawase, J., Automated determination of cationic surfactants by flow injection analysis based on ion-pair extraction, Anal. Chem., 52, 2124-2127 (1980).

14) Miller, B. and Young, R., Methodology for studying the wettability of filaments, Textile Res. J., 45, 359-365 (1975).

Penn, L.S. and Miller, B., A study of the primary cause of contact angle hysteresis on some polymeric solids, J. Colloid Interface Sci., 78, 238-240 (1980).

15) Good, B.J. and Girifalco, L.A., A theory for estimation of surface and interfacial energies. III, J. Am. Chem. Soc., 64, 561-565 (1960).

16) Ohno, K., Measurement of coefficient of friction of hair, Fragrance journal Japan, 10(3), 85-87 (1982).
Horiuchi, T., Kashiwa, Y., and Ohno, K., A new apparatus for the continuous recording of friction coefficient measurement of human hair, J. Soc. Cosmet. Chem. Japan, $14(1), 62-65$ (1980).

17) Okumura, T., Ishida, A., Sasaki, T., and Hayashi, S., Hair and brushing, J. Soc. Cosmet. Chem. Japan, 11(2), 5-11 (1977).

18) Garcia, M.L. and Diax, J., Combability measurements on human hair, J. Soc. Cosmet. Chem., 27, 379-398 (1976).

19) Kunieda, H. and Shinoda, K., Solution behavior of dialkyldimethylammonium chloride in water, J. Phys. Chem., 82, 1710-1714 (1978).

20) Nakamura, Y., Kamada, K., and Kondo, T., Hydrodynamic determination of critical surface tension of fibers, Sen-i Gakkaishi Japan, 26, 263-271 (1970).

21) Alter, H. and Cook, H., The effect of adsorbed water on the critical surface tension of hair, J. Colloid Interface Sci., 29, 439-443 (1969).

22). Owens, D.K., Friction of polymer films. I. Lubrication, J. Appl. Polym. Sci., 8, 14651475 (1964).

(平成 1 年 7 月 21 日受理) 